\title{
Article
}

\section{Analysis of the Local Health-Enhancing Physical Activity Policies on the French Riviera}

\author{
Antoine Noël Racine, Jean-Marie Garbarino, Bernard Massiera and Anne Vuillemin *(D) \\ Graduate School of Health Science Ecosystems, Université Côte d'Azur, Lamhess, 06200 Nice, France; \\ antoine.noel-racine@etu.univ-cotedazur.fr (A.N.R.); jean-marie.garbarino@univ-cotedazur.fr (J.-M.G.); \\ bernard.massiera@univ-cotedazur.fr (B.M.) \\ * Correspondence: anne.vuillemin@univ-cotedazur.fr; Tel.: +33-489-153-963
}

Citation: Racine, A.N.; Garbarino, J.-M.; Massiera, B.; Vuillemin, A. Analysis of the Local HealthEnhancing Physical Activity Policies on the French Riviera. Int. J. Environ. Res. Public Health 2021, 18, 156. https://doi.org/10.3390/ ijerph18010156

Received: 11 November 2020 Accepted: 21 December 2020 Published: 28 December 2020

Publisher's Note: MDPI stays neutral with regard to jurisdictional claims in published maps and institutional affiliations.

Copyright: (C) 2020 by the authors. Licensee MDPI, Basel, Switzerland. This article is an open access article distributed under the terms and conditions of the Creative Commons Attribution (CC BY) license (https: / / creativecommons.org/ licenses/by/4.0/).

\begin{abstract}
Policy is a lever for initiating the structural and environmental changes that foster healthenhancing physical activity (HEPA) promotion. However, little is known about the evidence in support of local governments regarding their HEPA-promoting policies. The aim of this study was to collect comprehensive information on municipal HEPA policies on the French Riviera (Alpes-Maritimes and Var counties) to provide an overview of the development of these policies in this territory. Mid-sized cities from the two counties constituting the French Riviera were targeted $(n=17)$. In each city, a local tool for HEPA policy analysis, CAPLA-Santé, was used to gain information from key informants heading the departments of sports, health services, and social services. Data were collected through semi-structured interviews and document analysis. Ten mid-sized cities volunteered to participate. Key informants from the sports $(n=10)$, health services $(n=5)$, and social services $(n=6)$ departments were interviewed. Written HEPA policy documents were formalized in six cities. These documents $(n=14)$ were mainly from the sports $(n=8)$ and health services $(n=4)$ sectors. The key informants reported that support from national policy, the commitment of elected officials, and large local stakeholder networks facilitated HEPA promotion, whereas the lack of intersectoral collaboration and limited resources were limitations. The results provide insight into the development of municipal HEPA policies, highlighting some of the barriers, facilitators, and perspectives. These findings could be valuable to scale up HEPA promotion at the local level.
\end{abstract}

Keywords: health promotion; physical activity; local government; policy analysis

\section{Introduction}

The health benefits of physical activity to prevent non-communicable diseases are well established [1,2]. Health-enhancing physical activity (HEPA) promotion is thus an important issue in the public health field $[3,4]$. Research has mostly focused on individual-level factors and showed that ecological models posit that the physical and social environments are important determinants of physical activity [5]. According to the literature, policy is one of the levers for initiating structural and environmental change to foster HEPA promotion [6-9]. The development of sustainable HEPA policies would provide people with a wide range of real opportunities to adopt physically active lifestyles [8,10-12]. It can be emphasized that the development of HEPA policies may be affected by the perceptions of the potential levers and barriers [13] and it has been shown that strong HEPA policy interventions have an impact on population health [8].

Nevertheless, the data on physical activity levels have shown that a significant part of the world's population is insufficiently physically active [14]. In France, 31\% of adults and 81\% of young people do not meet the World Health Organization (WHO) recommendations for physical activity (150 min per week for adults and $60 \mathrm{~min}$ per day for young people) [15,16]. Since the early 2000s, successive French national governments have developed HEPA policies to address the problem of physical inactivity [17-19]. 
However, solving this problem is a complex undertaking [20], and the involvement of national or federal governments alone is insufficient [21]. Effective HEPA promotion also requires the involvement of local governments, including a wide range of sectors and stakeholders $[6,21,22]$. Local governments are particularly suitable for implementing intersectoral policies to promote HEPA as they can more easily influence the conditions and environments where people live $[10,23,24]$. This means, of course, that a local government has to deal with a complex ecosystem embedded in a specific context [25].

Yet little evidence has emerged in support of local governments regarding their policies to promote HEPA [26]. A recent review exploring the published research on localgovernment HEPA policies indeed showed that the scientific literature on the topic remains scarce [27]. The analysis of local HEPA policies would therefore likely shed light on the gaps and opportunities in the initiatives of policymakers and researchers to increase the physical activity levels of various populations [28]. More extensive monitoring of HEPA promotion efforts through policy indicators would undoubtedly improve policymaking and policy decisions [8]. A better understanding of how local HEPA policies are developed and implemented would help provide suitable solutions to local governments. The aim of this study was to collect comprehensive information on municipal HEPA policies on the French Riviera to provide an overview of the development of these policies in this territory.

\section{Materials and Methods}

\subsection{Description of the CAPLA-Santé Tool}

CAPLA-Santé (Cadre d'Analyse des Politiques Locales Activité physique-SantéAnalysis framework of Local HEPA Policies), version. company, city, country, a tool for analyzing local HEPA policies, was developed in collaboration with the French Society of Public Health [29]. It is based on the WHO HEPA Policy Audit Tool (PAT) version 2, company, city, country $[28,30]$, which analyzes national HEPA policies. Briefly, a multidisciplinary and intersectoral group of experts, including researchers, professionals, and policymakers (national and local levels), was involved in developing CAPLA-Santé. The experts adapted each item of the HEPA PAT v2 to the local level (e.g., instead of asking leadership and collaboration at the national level, it was reformulated for the local level: Question 4 "Are there organizations or bodies which ensure cross-sectoral collaboration or coordination in implementing HEPA policies and action plans across the local government area studied?"). After a test within seven local governments to obtain feedback on the framework, a final workshop was organized to adjust and finalize it. The final version of CAPLA-Santé contains 21 items divided into six major sections: overview of HEPA stakeholders in the local government area, policy documents, policy contents, funding and political engagement, studies and measures related to physical activity in the local government area, and progress achieved and future challenges.

\subsection{Participants}

Mid-sized municipalities (between 20,000 and 100,000 residents according to the National Institute of statistics and economic studies (INSEE) [31]) from the French Riviera (Alpes-Maritimes and Var counties) were invited to participate in this study $(n=17)$. Midsize municipalities were chosen to ensure more homogeneous municipalities; smaller ones have fewer resources to develop HEPA policies and there are only two big municipalities (over 100,000 inhabitants) with a different magnitude of resources compared with mid-size municipalities. Municipalities were initially contacted by e-mail. If necessary, a phone call was organized to provide more detail on the research project. The municipalities that volunteered to participate in the project were included in the study. Data on the characteristics of each municipality (number of inhabitants, median income per inhabitant, number of people affected by a chronic illness) were collected from the Regional Health Observatory of Provence-Alpes-Côte d'Azur database [32]. In each municipality, the objective was to recruit a minimum of two key informants from three main sectors: sports, health services, and social services. 


\subsection{Data Collection and Analysis}

Data were collected between September 2018 and March 2019 from two sources: written HEPA policy documents collected from the internet (municipality websites) and key informants from the sports, health services, and social services sectors of the municipalities included in this study. The definition of a written HEPA policy document used in this study was the one used in CAPLA-Santé: "Written document that contains priorities, defines goals and objectives, and usually comes from a specific sector of public administration" [29]. To be reviewed, the HEPA policy documents had to have a clearly expressed health objective. The content of these documents was analyzed using the items and major sections of the CAPLA-Santé. Through semi-structured interviews, face to face or by phone, all items of the CAPLA-Santé were addressed to the key informants from the sports, services, and social services sectors to elicit their responses. Each interview was digitally recorded and transcribed verbatim. After data analysis, a final report and a synthesis of the CAPLASanté results were provided to each municipality. Data from each municipality were added to a matrix including all items of CAPLA-Santé for a global analysis. Ethical approval was obtained from Université Côte d'Azur before starting the study under the reference UCA-E19-011.

\section{Results}

\subsection{Participants}

Among the 17 invited mid-sized municipalities, 10 volunteered to participate in this study. In these municipalities, 21 key informants heading the departments of sports $(n=10)$, health services $(n=5)$, social services $(n=5)$, and the department of sports and social services $(n=1)$ were involved. Table 1 presents the characteristics of the municipalities and key informants interviewed.

Table 1. Characteristics of the municipalities and key informants.

\begin{tabular}{|c|c|c|c|c|c|}
\hline Municipality & Inhabitants $(n) *$ & $\begin{array}{l}\text { Median Income } \\
(€) * *\end{array}$ & $\begin{array}{l}\text { People Affected by a } \\
\text { Chronic Illness }(n) * * *\end{array}$ & $\begin{array}{l}\text { Key Informant } \\
\text { Position }\end{array}$ & Sector Position \\
\hline \multirow[t]{2}{*}{$\mathrm{A}$} & 74,875 & 22,392 & 12,441 & HD & social \\
\hline & & & & $\begin{array}{c}\text { Head of HEPA }+ \\
\text { project } \\
\text { Project officer }\end{array}$ & $\begin{array}{l}\text { sport } \\
\text { health }\end{array}$ \\
\hline \multirow[t]{2}{*}{ B } & 49,322 & 22,046 & 8012 & HD & social \\
\hline & & & & HD & sport \\
\hline \multirow[t]{2}{*}{ C } & 28,919 & 22,858 & 4592 & HD & social \\
\hline & & & & HD & sport \\
\hline $\mathrm{D}$ & 50,937 & 20,704 & 7607 & HD & sport and social \\
\hline \multirow[t]{2}{*}{$\mathrm{E}$} & 41,571 & 20,010 & 7250 & HD & sport \\
\hline & & & & HD & health \\
\hline \multirow[t]{2}{*}{ F } & 35,296 & 23,152 & 6913 & HD & sport \\
\hline & & & & HD & health \\
\hline \multirow[t]{2}{*}{ G } & 64,903 & 18,656 & 11,305 & HD & sport \\
\hline & & & & HD & health \\
\hline \multirow{2}{*}{$\mathrm{H}$} & & & & HD & sport \\
\hline & 74,285 & 18,962 & 14,369 & HD & social \\
\hline \multirow[t]{2}{*}{ I } & 25,047 & 20,940 & 4656 & HD & social \\
\hline & & & & HD & sport \\
\hline \multirow[t]{3}{*}{$\mathrm{J}$} & 23,347 & 21,778 & 3342 & HD & social \\
\hline & & & & HD & sport \\
\hline & & & & HD & health \\
\hline
\end{tabular}

Note: Head of the department (HD) * Data from the National Institute of Statistics and Economic Studies-INSEE (2018). ${ }^{* *}$ Data from INSEE (2018). ${ }^{* * *}$ Number of people affected by a chronic illness covered by government insurance for their healthcare expenditures. Data from the Regional Health Observatory of Provence-Alpes-Côte d'Azur (2018). + HEPA: health-enhancing physical activity 


\subsection{Data Collection and Analysis}

The average time of the semi-structured interviews was $35 \mathrm{~min}$.

\subsubsection{Section 1: Overview of HEPA Stakeholders in the Local Government Area}

The key informants from the municipalities identified an average of four public agencies engaged in HEPA promotion in their territory. These agencies were mainly from the sports $(n=15)$, health services $(n=13)$, and education $(n=6)$ sectors. Among the 10 municipalities included in this study, six considered themselves leaders in pushing forward HEPA promotion within their territory, three had a department head who ensured cross-sectoral collaboration or coordination in implementing the HEPA policies, and five had connections with a HEPA promotion network. Table 2 presents the section details for each municipality.

Table 2. Overview of HEPA stakeholders in the local government area.

\begin{tabular}{|c|c|c|c|c|c|}
\hline Municipality & $\begin{array}{c}\text { Sectors and Public Agencies } \\
\text { (n) Engaged in HEPA } \\
\text { Promotion }\end{array}$ & $\begin{array}{c}\text { Non-Governmental } \\
\text { Stakeholders }(n) \text { Engaged in } \\
\text { HEPA Promotion }\end{array}$ & $\begin{array}{l}\text { Leadership } \\
\text { Identified }\end{array}$ & $\begin{array}{l}\text { Coordinator } \\
\text { Identified }\end{array}$ & $\begin{array}{l}\text { Connections with } \\
\text { HEPA Network }\end{array}$ \\
\hline A & $\begin{array}{l}\text { sport }(n=2), \text { health }(n=1), \\
\text { multisectoral }(n=1)\end{array}$ & $\begin{array}{c}\text { insurance and private sport } \\
(n=2), \text { sport }(n=1) \\
\text { health }(n=1)\end{array}$ & municipality & sports department & yes \\
\hline B & $\begin{array}{c}\text { sport }(n=3) \text {, multisectoral } \\
(n=2) \text { health }(n=1) \text {, education } \\
(n=1)\end{array}$ & sport $(n=1)$, health $(n=1)$ & municipality & - & yes \\
\hline $\mathrm{C}$ & $\begin{array}{c}\text { sport }(n=2), \text { health }(n=1) \\
\text { social }(n=1), \text { multisectoral } \\
(n=1)\end{array}$ & $\begin{array}{l}\text { sport }(n=3) \text {, health }(n=2) \text {, } \\
\text { insurance and private sport } \\
(n=2)\end{array}$ & municipality & - & yes \\
\hline $\mathrm{D}$ & $\begin{array}{l}\text { health }(n=3), \text { education }(n 2) \text {, } \\
\text { sport }(n=1),\end{array}$ & sport $(n=1)$ & - & - & - \\
\hline $\mathrm{E}$ & sport $(n=2)$, health $(n=1)$ & sport $(n=1)$, health $(n=1)$ & - & - & - \\
\hline $\mathrm{F}$ & multisectoral $(n=1)$ & $\begin{array}{c}\text { sport }(n=1) \text {, health }(n=1) \text {, } \\
\text { insurance }(n=1)\end{array}$ & - & - & none \\
\hline G & $\begin{array}{c}\text { health }(n=3), \text { sport }(n=2) \text {, } \\
\text { education }(n=1) \\
\text { multisectoral }(n=1)\end{array}$ & $\begin{array}{c}\text { health }(n=2), \text { private sport } \\
(n=1) \\
\text { sport }(n=1)\end{array}$ & municipality & $\begin{array}{l}\text { social services } \\
\text { department }\end{array}$ & yes \\
\hline $\mathrm{H}$ & $\begin{array}{l}\text { sport }(n=1), \text { health }(n=1), \\
\text { education }(n=1)\end{array}$ & sport $(n=1)$, health $(n=1)$ & municipality & Health services & yes \\
\hline I & health $(n=2)$, sport $(n=1)$, & $\begin{array}{c}\text { sport }(n=1), \text { health }(n=1) \\
\text { education }(n=1)\end{array}$ & municipality & - & - \\
\hline $\mathrm{J}$ & sport $(n=1)$, education $(n=1)$ & sport $(n=1)$, education $(n=1)$ & - & - & - \\
\hline
\end{tabular}

\subsubsection{Section 2: Policy Documents}

Fourteen written HEPA policy documents collected from six municipalities were reviewed (Figure 1). These policy documents were from the sports $(n=8)$, health services $(n=4)$, social services $(n=1)$, and environment $(n=1)$ sectors.

\subsubsection{Section 3: Policy Contents}

Of the 14 written HEPA policy documents, none included quantitative objectives. The objectives expressed in these documents differed according to the sector and the target audience, such as "to improve the health of people suffering from chronic diseases through physical activity", or "to facilitate access to free and outdoor physical activity in line with the public health recommendations" or "to maintain the independence of elderly people with physical activity." Table 3 provides details on the contents of the policies for each municipality. 
Number of policies $(n=14)$

5

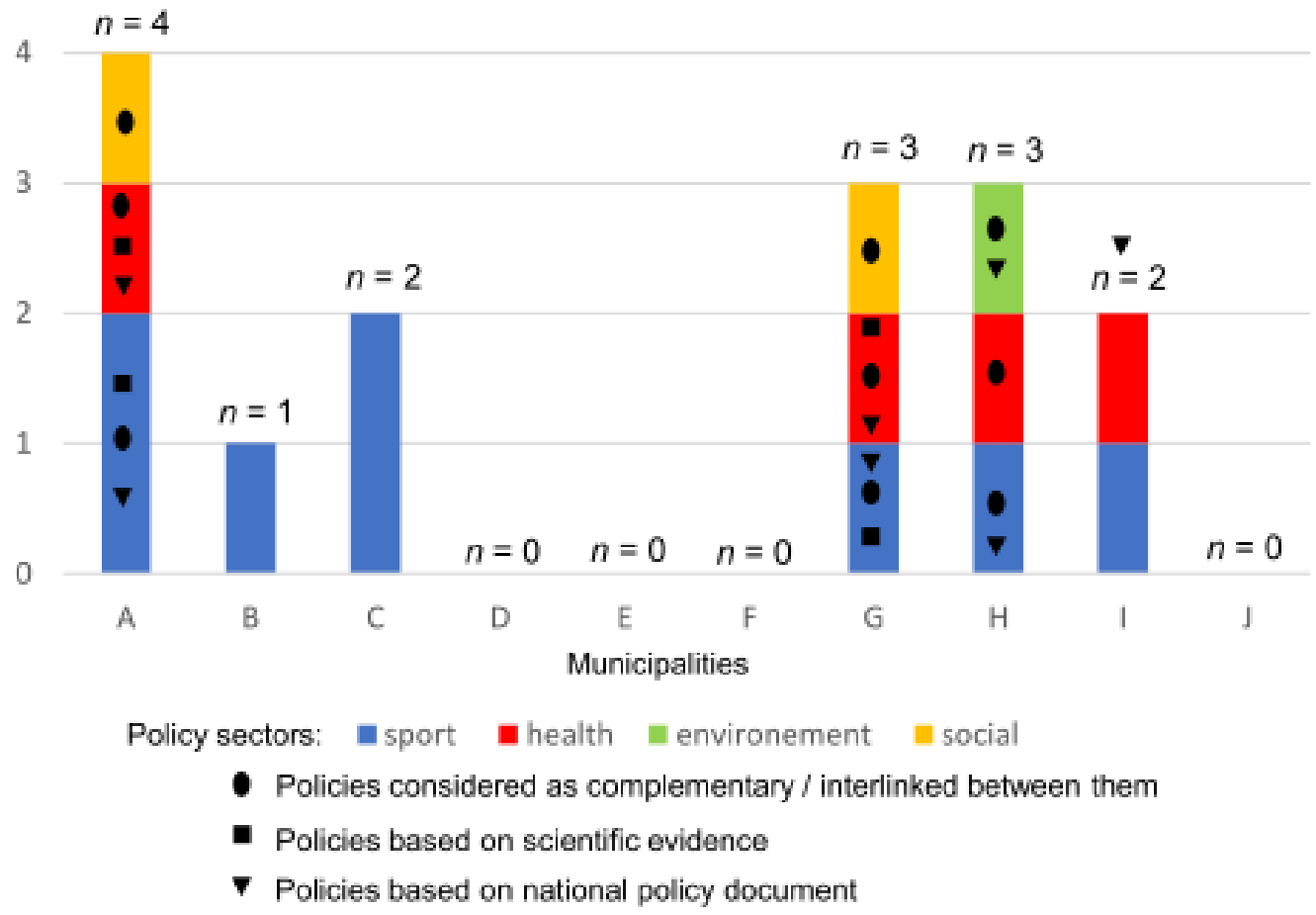

Figure 1. HEPA policy documents collected from municipalities.

Table 3. Policy contents.

\begin{tabular}{|c|c|c|c|c|}
\hline Municipality & Policy Settings & Target Audiences & $\begin{array}{c}\text { Communication Strategies } \\
\text { or Actions }\end{array}$ & Concrete Actions \\
\hline A & $\begin{array}{c}\text { sports and leisure } \\
\text { urban environment } \\
\text { health and social care centers }\end{array}$ & $\begin{array}{l}\text { general population } \\
\text { seniors } \\
\text { inactive and people suffering from } \\
\text { chronic diseases }\end{array}$ & $\begin{array}{c}\text { website } \\
\text { social networks } \\
\text { local newspapers events } \\
\text { awareness of healthcare } \\
\text { professional }\end{array}$ & $\begin{array}{l}\mathrm{PA} * \text { program } \\
\text { fitness trails }\end{array}$ \\
\hline B & sports and leisure & sedentary people & $\begin{array}{l}\text { website } \\
\text { events } \\
\text { website }\end{array}$ & PA program \\
\hline $\mathrm{C}$ & sports and leisure & seniors & $\begin{array}{l}\text { social networks } \\
\text { local newspapers }\end{array}$ & PA program \\
\hline $\mathrm{D}$ & no data & no data & no data & no data \\
\hline E & no data & no data & no data & no data \\
\hline F & no data & no data & $\begin{array}{l}\text { website } \\
\text { social networks }\end{array}$ & $\begin{array}{c}\text { events promoting PA for } \\
\text { heath }\end{array}$ \\
\hline $\mathrm{H}$ & $\begin{array}{l}\text { sports and leisure } \\
\text { tourism } \\
\text { urban environment } \\
\text { sports and leisure }\end{array}$ & $\begin{array}{l}\text { general population } \\
\text { inactive people } \\
\text { pre-school and children }\end{array}$ & $\begin{array}{l}\text { website } \\
\text { social networks } \\
\text { events }\end{array}$ & $\begin{array}{c}\text { outdoor fitness and trail } \\
\text { network } \\
\text { HEPA events }\end{array}$ \\
\hline I & $\begin{array}{l}\text { primary school } \\
\text { priority neighborhoods for } \\
\text { urban policy }\end{array}$ & $\begin{array}{l}\text { seniors } \\
\text { children }\end{array}$ & $\begin{array}{l}\text { website } \\
\text { social networks }\end{array}$ & PA programs \\
\hline $\mathrm{J}$ & no data & no data & no data & no data \\
\hline
\end{tabular}

* PA: physical activity.

\subsubsection{Section 4: Funding and Political Engagement}

Only the municipalities that had a HEPA policy $(n=6)$ identified funding sources to implement these policies. Most of the funds were provided by other government bodies at local and national levels, such as the Agence Régionale de santé (i.e., the Regional Health Agency), Agenda 21 (i.e., an environmental action plan to be implemented at local level), and the Conférence des Financeurs de la Prevention de la Perte d'Autonomie (i.e., the County Conference of Funders for the Prevention of Loss of Autonomy). Municipality 
"A" also identified funding from the private sector (insurance). No source of funding was recurring (1-year maximum).

\subsubsection{Section 5: Studies and Measures Relating to Physical Activity in the Local} Government Area

No municipality reported a surveillance system related to physical activity. Municipality " $\mathrm{A}$ " conducted two surveys from a HEPA policy development perspective: one to explore the physical activity expectations and needs of the target audience and one to measure obesity in the schools. No municipality reported a cost-benefit study related to physical activity.

\subsubsection{Section 6: Progress Achieved and Future Challenges}

Table 4 summarizes the key moments in the development of the municipal HEPA policies, the strengths and weaknesses in developing them, and the progress achieved and future challenges.

Table 4. Synthesis of Section 6: progress achieved and future challenges.

\begin{tabular}{|c|c|c|c|c|c|}
\hline Municipality & Keys Moments & Strengths & Weaknesses & Progress & Challenges \\
\hline A & $\begin{array}{l}\text { national legislation of } \\
\text { physical activity } \\
\text { prescription; local } \\
\text { conference on the topic }\end{array}$ & $\begin{array}{l}\text { local stakeholder network; } \\
\text { geographic situation; } \\
\text { sportsfacilities; presence of } \\
\text { PA and health professionals }\end{array}$ & $\begin{array}{l}\text { limited resources; lack of } \\
\text { cycle path network }\end{array}$ & $\begin{array}{l}\text { implementation of } \\
\text { HEPA actions }\end{array}$ & $\begin{array}{l}\text { formalize global HEPA } \\
\text { action; develop HEPA } \\
\text { events; identify recurring } \\
\text { funding to sustain HEPA } \\
\text { policies }\end{array}$ \\
\hline B & $\begin{array}{l}\text { pilot implementation of } \\
\text { PA program }\end{array}$ & $\begin{array}{l}\text { local stakeholder network; } \\
\text { quality and number of PA } \\
\text { facilities }\end{array}$ & $\begin{array}{c}\text { lack of intersectoral } \\
\text { coordination; geographic } \\
\text { difficulties in accessing PA } \\
\text { facilities }\end{array}$ & $\begin{array}{l}\text { sustainment of a PA } \\
\text { pilot program for } \\
\text { seniors to a regular } \\
\text { program }\end{array}$ & $\begin{array}{l}\text { improve stakeholder } \\
\text { coordination; identify } \\
\text { recurring findings to sustain } \\
\text { HEPA policies; develop } \\
\text { public space to practice PA }\end{array}$ \\
\hline $\mathrm{C}$ & $\begin{array}{l}\text { mayor's willingness to } \\
\text { promote PA }\end{array}$ & $\begin{array}{l}\text { local stakeholder network; } \\
\text { geographic situation }\end{array}$ & $\begin{array}{l}\text { few PA programs available } \\
\text { for sedentary and inactive } \\
\text { people; lack of resources; } \\
\text { overuse of PA facilities }\end{array}$ & $\begin{array}{l}\text { implementation of } \\
\text { HEPA actions }\end{array}$ & $\begin{array}{l}\text { develop human resources } \\
\text { with PA and health training; } \\
\text { identify recurring funding to } \\
\text { sustain HEPA policies }\end{array}$ \\
\hline $\mathrm{D}$ & no data & local stakeholder network & $\begin{array}{l}\text { unwillingness to develop } \\
\text { policy; difficulties moving in } \\
\text { the city without a car; lack of } \\
\text { resources }\end{array}$ & no data & $\begin{array}{l}\text { build willingness to develop } \\
\text { a policy; develop a global } \\
\text { intersectoral HEPA policy }\end{array}$ \\
\hline $\mathrm{E}$ & no data & knowledge of the territory & lack of resources & no data & $\begin{array}{l}\text { develop active mobility; } \\
\text { develop a HEPA plan }\end{array}$ \\
\hline $\mathrm{F}$ & no data & $\begin{array}{l}\text { local stakeholder network; } \\
\text { quality and number of sports } \\
\text { facilities; knowledge of the } \\
\text { local context }\end{array}$ & $\begin{array}{l}\text { unwillingness to develop } \\
\text { policy; lack of knowledge in } \\
\text { PA and health, lack of } \\
\text { intersectoral collaboration }\end{array}$ & no data & $\begin{array}{l}\text { formalize a HEPA policy; } \\
\text { develop a campaign to } \\
\text { sensitize residents }\end{array}$ \\
\hline G & $\begin{array}{l}\text {-national policy to } \\
\text { promote PA }\end{array}$ & $\begin{array}{l}\text { local stakeholder network; } \\
\text { culture of sport; global } \\
\text { vision of health }\end{array}$ & $\begin{array}{c}\text { lack of resources and PA } \\
\text { facilities }\end{array}$ & $\begin{array}{l}\text { implementation of } \\
\text { HEPA actions }\end{array}$ & $\begin{array}{l}\text { develop a global HEPA } \\
\text { project from children to } \\
\text { older people }\end{array}$ \\
\hline $\mathrm{H}$ & $\begin{array}{l}\text {-mandate of the mayor; } \\
\text { national HEPA } \\
\text { campaign }\end{array}$ & $\begin{array}{c}\text { local stakeholder network, } \\
\text { geographic situation; } \\
\text { willingness of the mayor; PA } \\
\text { facilities }\end{array}$ & overcrowed PA facilities & $\begin{array}{l}\text { implementation of } \\
\text { HEPA actions }\end{array}$ & $\begin{array}{l}\text { target more inactive people; } \\
\text { develop more cyclable paths }\end{array}$ \\
\hline I & $\begin{array}{l}\text {-national policy to } \\
\text { promote PA }\end{array}$ & $\begin{array}{l}\text { geographic situation; PA } \\
\text { facilities; good } \\
\text { communication }\end{array}$ & lack of resources & $\begin{array}{l}\text { implementation of } \\
\text { HEPA actions }\end{array}$ & $\begin{array}{c}\text { target more inactive people; } \\
\text { develop a global } \\
\text { intersectoral HEPA policy } \\
\text { with dedicated human } \\
\text { resources }\end{array}$ \\
\hline $\mathrm{J}$ & no data & $\begin{array}{l}\text { local network of } \\
\text { stakeholders }\end{array}$ & $\begin{array}{c}\text { lack of PA facilities and lack } \\
\text { of public open space }\end{array}$ & no data & $\begin{array}{l}\text { build willingness to develop } \\
\text { a policy; develop a global } \\
\text { HEPA policy with the } \\
\text { metropolis }\end{array}$ \\
\hline
\end{tabular}

\section{Discussion}

The results provided an overview of HEPA policy development in mid-sized municipalities from the French Riviera. They also helped identify the stakeholders that should be involved in HEPA policymaking at the local level, the types of HEPA policies that mid-sized French municipalities are able to develop, and the factors that are likely to facili- 
tate or limit their development. Last, the results pointed to perspectives on HEPA policy development that might be explored and provided future research and practice directions. For example, we showed that when a dense network of stakeholders was involved in HEPA promotion within the territory, the municipalities formalized more of the written policy documents. Similarly, most of the municipalities with written HEPA policy documents had connections with a HEPA network. Although this cross-data analysis indicated no cause-effect relationship, it suggested that HEPA promotion as an item on the municipal policy agenda might be facilitated by advocacy from a local HEPA network.

A theory often used to determine how an issue such as HEPA promotion finds a place on the policy agenda is the Multiple Streams Approach (MSA) [33]. According to Kingdon et al. (1995), the advocacy of a strong "policy entrepreneur" such as a stakeholder network can facilitate the opening of a "policy window" through which an issue finds a place on the policy agenda [21]. Using the MSA with data collected from the CAPLA-Santé tool in a range of contexts and with additional municipalities might well highlight the influence of local stakeholder networks on the policy agendas of municipalities in general. It would then be interesting to explore how strong local advocacy can stimulate and scale up the development of HEPA policies [34].

In addition, national advocacy might also stimulate and scale up the development of these local policies. The results from the section on policy documents showed that the municipalities that had the most and most varied HEPA policies had based their policies on national policy and/or research evidence. Although in line with the literature [6,22,35] and the WHO recommendations [11,12], there is still a need to better understand the influence between national and local HEPA policies and better translate research evidence to policymaking [8].

Another direction for investigation concerns the opportunities and difficulties that municipalities encounter using an environmental approach $[6,7,36]$. In this study, the municipalities rarely implemented concrete actions based on this approach, which is not in line with the literature $[6,7,36]$. Studies have shown that HEPA policies should prioritize environmental approaches, such as developing active transport, green parks, and open spaces, over individual approaches $[7,8,10,36]$. Moreover, doing so makes it easier to target a larger proportion of the population. The difficulty of adopting an environmental approach could be partially explained by a lack of intersectoral collaboration [37-39]. Our data showed that for the municipalities that had HEPA policies, few sectors were involved outside of sports and health services, with, for example, the urban and environment sectors rarely involved. Yet, it has been well documented that an intersectoral approach is needed to achieve an effective HEPA policy [6,8]. A dependable bridge from the latest research evidence to the policymakers may thus be crucial to ensure the effectiveness of HEPA policies [40].

A surveillance system is also important to ensure the provision of relevant information to guide the development, implementation, and adaptation of HEPA policies [8,41]. However, no municipality in this study had a surveillance system for PA or sedentary behavior. This type of surveillance should be based on repeated measures to provide data on PA and sedentary behaviors, as well as the associated factors [41]. Moreover, for municipalities that have a surveillance system, it is probably not a priority, given the frequent budget constraints and limited human resources for running it. Nevertheless, with the emergence of smartphone accelerometers and applications to measure PA [8,42], municipalities now have a great opportunity to set up a surveillance system with few resources.

This study had certain limitations. The HEPA policy analysis was limited to two counties in France. Moreover, only mid-sized municipalities were recruited in these counties. We assumed that smaller municipalities (fewer than 20,000 inhabitants according to INSEE [31]) would have even fewer resources to develop HEPA policies than midsize municipalities, whereas big municipalities (more than 100,000 inhabitants according INSEE [29]) would have more but would be more complex to analyze. In addition, the magnitude of the resources may have differed across the mid-sized municipalities as it was 
difficult to assemble a homogeneous sample of municipalities. Similarly, it was difficult to recruit key informants who had enough time to participate in this study. Those that we interviewed were from only three sectors (sports, health services, and social services) and information from other sectors, such as the urban or environment sectors, may have been missed. Last, the data from the interviews may have been biased due to social and political desirability [43]. However, the strengths of this study should be emphasized. Few studies were interested in local HEPA policies in several municipalities. A standardized framework was used to collect data on HEPA policies which provide an overview and allow comparison. This study represents the first step in the implementation of a follow-up of these policies, using the CAPLA-Sante which aims to capture the progress and experiences on developing local HEPA policies.

\section{Conclusions}

This study collected comprehensive information on local HEPA policies on the French Riviera in order to obtain an overview of the HEPA policies within this territory. Our results may contribute to a better understanding of the development of local HEPA policies as they highlight some of the barriers, facilitators, and perspectives. The CAPLA-Santé tool was able to provide policy information that may be helpful to policymakers in their future HEPA policy decisions. It could help to enhance or strengthen the capacity-building of local governments as they develop HEPA policies. Nevertheless, municipalities may need to be more systematic about adopting intersectoral and environmental approaches to enhance the promotion of physical activity. Further studies in different contexts, including cities with a greater number of inhabitants, as well as reviews of HEPA policy development and implementation, and research translation into practice are now needed to help implement these approaches.

Author Contributions: Conceptualization, A.N.R. and A.V.; methodology, A.N.R., A.V., B.M. and J.-M.G.; validation, A.V., B.M. and J.-M.G.; formal analysis, A.N.R.; investigation, A.N.R.; resources, A.V., B.M. and J.-M.G.; data curation, A.V.; writing-original draft preparation, A.N.R.; writingreview and editing, A.N.R., A.V.; visualization, A.V., J.-M.G.; supervision, A.V. All authors have read and agreed to the published version of the manuscript.

Funding: This research was funded by the Région Sud Provence-Alpes-Côte d'Azur under a PhD grant and co-funded by the association Azur Sport Santé.

Institutional Review Board Statement: Ethical approval was obtained on 20 March 2019 from Université Côte d'Azur before starting the study under the reference UCA-E19-011.

Informed Consent Statement: Informed consent was obtained from all subjects involved in the study.

Data Availability Statement: The data that support the findings of this study are available from the corresponding author, upon reasonable request.

Acknowledgments: We would like to thank the department heads and elected officials who participated in this study.

Conflicts of Interest: The authors declare no conflict of interest.

\section{References}

1. Lee, I.-M.; Shiroma, E.J.; Lobelo, F.; Puska, P.; Blair, S.N.; Katzmarzyk, P.T.; Group, L.P.A.S.W. Effect of physical inactivity on major non-communicable diseases worldwide: An analysis of burden of disease and life expectancy. Lancet 2012, 380, 219-229. [CrossRef]

2. Reiner, M.; Niermann, C.; Jekauc, D.; Woll, A. Long-term health benefits of physical activity-a systematic review of longitudinal studies. BMC Public Health 2013, 13, 813. [CrossRef] [PubMed]

3. International Society for Physical Activity and Health. The Toronto Charter for Physical Activity: A Global Call for Action. J. Phys. Act. Health 2010, 7, 370-385. [CrossRef] [PubMed]

4. International Society for Physical Activity and Health. The Bangkok Declaration on Physical Activity for Global Health and Sustainable Development. Br. J. Sports Med. 2017, 51, 1389-1391. [CrossRef] [PubMed]

5. Bauman, A.E.; Reis, R.S.; Sallis, J.F.; Wells, J.C.; Loos, R.J.F.; Martin, B.W. Correlates of physical activity: Why are some people physically active and others not? Lancet 2012, 380, 258-271. [CrossRef] 
6. $\quad$ Reis, R.S.; Salvo, D.; Ogilvie, D.; Lambert, E.V.; Goenka, S.; Brownson, R.C. Scaling up physical activity interventions worldwide: Stepping up to larger and smarter approaches to get people moving. Lancet 2016, 388, 1337-1348. [CrossRef]

7. Golden, S.D.; McLeroy, K.R.; Green, L.W.; Earp, J.A.L.; Lieberman, L.D. Upending the Social Ecological Model to Guide Health Promotion Efforts Toward Policy and Environmental Change. Health Educ. Behav. 2015, 42, 8S-14S. [CrossRef]

8. Ding, D.; Ramirez Varela, A.; Bauman, A.E.; Ekelund, U.; Lee, I.M.; Heath, G.; Katzmarzyk, P.T.; Reis, R.; Pratt, M. Towards better evidence-informed global action: Lessons learnt from the Lancet series and recent developments in physical activity and public health. Br. J. Sports Med. 2020, 54, 462-468. [CrossRef]

9. Pratt, M.; Perez, L.G.; Goenka, S.; Brownson, R.C.; Bauman, A.; Sarmiento, O.L.; Hallal, P.C. Can Population Levels of Physical Activity Be Increased? Global Evidence and Experience. Prog. Cardiovasc. Dis. 2015, 57, 356-367. [CrossRef]

10. Wilkinson, R. The Solid Fact-promoting Physical Activity and Active Living in Urban Environments-the Role of Local Governments: WHO Regional Publications, European Series No. 89; World Health Organization: Geneva, Switzerland, 2006; ISBN 9289021810.

11. World Health Organization. More Active People for a Healthier World: Global Action Plan on Physical Activity 2018-2030; World Health Organization: Geneva, Switzerland, 2018; ISBN 9789241514187.

12. World Health Organization. Physical Activity Strategy for the WHO European Region 2016-2025; World Health Organization: Geneva, Switzerland, 2016.

13. Noël Racine, A.; Garbarino, J.M.; Corrion, K.; D’Arripe-Longueville, F.; Massiera, B.; Vuillemin, A. Perceptions of barriers and levers of health-enhancing physical activity policies in mid-size French municipalities. Health Res. Policy Syst. 2020, 18, 1-10. [CrossRef]

14. Guthold, R.; Stevens, G.A.; Riley, L.M.; Bull, F.C. Worldwide trends in insufficient physical activity from 2001 to 2016 : A pooled analysis of 358 population-based surveys with 1.9 million participants. Lancet. Glob. Health 2018, 6, e1077-e1086. [CrossRef]

15. World Health Organization. France-Physical Activity Factsheet (2018); World Health Organization: Geneva, Switzerland, 2018.

16. World Health Organization. Global Recommendations on Physical Activity for Health; World Health Organization: Geneva, Switzerland, 2010.

17. Prévot-Ledrich, J.; Van Hoye, A.; Lombrail, P.; Lecomte, F.; Vuillemin, A. Panorama des politiques publiques françaises de promotion de l'activité physique bénéfique pour la santé. Sante Publique 2016, 28, S25-S31. [CrossRef] [PubMed]

18. Daugbjerg, S.B.; Kahlmeier, S.; Racioppi, F.; Martin-Diener, E.; Martin, B.; Oja, P.; Bull, F. Promotion of physical activity in the European region: Content analysis of 27 national policy documents. J. Phys. Act. Health 2009, 6, 805-817. [CrossRef] [PubMed]

19. Van Hoye, A.; Vandoorne, C.; Absil, G.; Lecomte, F.; Fallon, C.; Lombrail, P.; Vuillemin, A. Health enhancing physical activity in all policies? Comparison of national public actors between France and Belgium. Health Policy 2019, 123, 327-332. [CrossRef]

20. Kohl, H.W.; Craig, C.L.; Lambert, E.V.; Inoue, S.; Alkandari, J.R.; Leetongin, G.; Kahlmeier, S.; Andersen, L.B.; Bauman, A.E.; Blair, S.N.; et al. The pandemic of physical inactivity: Global action for public health. Lancet 2012, 380, 294-305. [CrossRef]

21. Rütten, A.; Abu-Omar, K.; Gelius, P.; Schow, D. Physical inactivity as a policy problem: Applying a concept from policy analysis to a public health issue. Health Res. Policy Syst. 2013, 11, 9. [CrossRef]

22. Vuori, I.; Lankenau, B.; Pratt, M. Physical activity policy and program development: The experience in Finland. Public Health Rep. 2004, 119, 331-345. [CrossRef]

23. Guglielmin, M.; Muntaner, C.; O'Campo, P.; Shankardass, K. A scoping review of the implementation of health in all policies at the local level. Health Policy 2018, 122, 284-292. [CrossRef]

24. World Health Organization. Healthy Cities Promoting Health and Equity-Evidence for Local Policy and Practice; World Health Organization Europe: Copenhagen, Denmark, 2014.

25. Spitters, H.P.E.M.; Lau, C.J.; Sandu, P.; Quanjel, M.; Dulf, D.; Glumer, C.; van Oers, H.A.M.; van de Goor, I.A.M. Unravelling networks in local public health policymaking in three European countries-a systems analysis. Health Res. Policy Syst. 2017, 15, 5. [CrossRef]

26. Bull, F. Translating science to inform global policy on physical activity. J. Sport Health Sci. 2018, 7, 3-4. [CrossRef]

27. Noël Racine, A.; Van Hoye, A.; Boyd, A.; Jackson, F.; Garbarino, J.M.; Massiera, B.; Kahlmeier, S.; Sandu, P.; Vuillemin, A. A scoping review of published research on local government policies promoting health-enhancing physical activity. Int. J. Sport Policy Polit. 2020, 12, 747-763. [CrossRef]

28. Bull, F.C.; Milton, K.; Kahlmeier, S. National policy on physical activity: The development of a policy audit tool. J. Phys. Act. Health 2014, 11, 233-240. [CrossRef] [PubMed]

29. Noël Racine, A.; Van Hoye, A.; Baron, A.; Lecomte, F.; Garbarino, J.M.; Massiera, B.; Honta, M.; Vuillemin, A. Development of a Local Health-Enhancing Physical Activity Policy Analysis Tool in France: CAPLA-Santé. Health Promot. Pract. 2020. [CrossRef] [PubMed]

30. World Health Organization. Health-Enhancing Physical Activity (HEPA) Policy Audit Tool (PAT)-Version 2 (2015); World Health Organization: Geneva, Switzerland, 2015.

31. Institut National de la Statistique et des Etudes Economiques. Available online: https://www.insee.fr/fr/accueil (accessed on 9 October 2019).

32. Observatoire Régional de la Santé Provence-Alpes-Côte d'Azur. SIRSéPACA. Available online: http://www.sirsepaca.org (accessed on 11 May 2020).

33. King, A.; John, W. Kingdon, Agendas, Alternatives, and Public Policies, Boston: Little, Brown, 1984, xi + 240 pp., \$9.95. J. Public Policy 1985, 5, 281-283. [CrossRef] 
34. McKay, H.; Naylor, P.J.; Lau, E.; Gray, S.M.; Wolfenden, L.; Milat, A.; Bauman, A.; Race, D.; Nettlefold, L.; Sims-Gould, J. Implementation and scale-up of physical activity and behavioural nutrition interventions: An evaluation roadmap. Int. J. Behav. Nutr. Phys. Act. 2019, 16, 1-12. [CrossRef] [PubMed]

35. Woods, C.B.; Mutrie, N. Putting physical activity on the policy agenda. Quest 2012, 64, 92-104. [CrossRef]

36. Giles-Corti, B.; Vernez-Moudon, A.; Reis, R.; Turrell, G.; Dannenberg, A.L.; Badland, H.; Foster, S.; Lowe, M.; Sallis, J.F.; Stevenson, M.; et al. City planning and population health: A global challenge. Lancet 2016, 388, 2912-2924. [CrossRef]

37. Coghill, C.L.; Valaitis, R.K.; Eyles, J.D. Built environment interventions aimed at improving physical activity levels in rural Ontario health units: A descriptive qualitative study Health policies, systems and management. BMC Public Health 2015, 15. [CrossRef]

38. Lemon, S.C.; Goins, K.V.; Schneider, K.L.; Brownson, R.C.; Valko, C.A.; Evenson, K.R.; Eyler, A.A.; Heinrich, K.M.; Lyn, R.; Litt, J.; et al. Municipal officials' participation in built environment policy development in the United States. Am. J. Health Promot. 2015, 30, 42-49. [CrossRef]

39. Thomas, M.M.; Hodge, W.; Smith, B.J. Building capacity in local government for integrated planning to increase physical activity: Evaluation of the VicHealth MetroACTIVE program. Health Promot. Int. 2009, 24. [CrossRef]

40. Brownson, R.C.; Jones, E. Bridging the gap: Translating research into policy and practice. Prev. Med. 2009, 49, 313-315. [CrossRef] [PubMed]

41. Rivière, F. Contribution to the Surveillance and Measurement of Physical Activity and Sedentary Behaviors. Ph.D. Thesis, Université de Lorraine, Nancy, France, 13 December 2017.

42. Althoff, T.; Sosič, R.; Hicks, J.L.; King, A.C.; Delp, S.L.; Leskovec, J. Large-scale physical activity data reveal worldwide activity inequality. Nature 2017, 547, 336-339. [CrossRef] [PubMed]

43. Lavrakas, P. Encyclopedia of Survey Research Methods; SAGE Publications: Thousand Oaks, CA, USA, 2008. 